\title{
Validity of learning website of kapita selekta mathematics course at UIN Suska Riau Students
}

\author{
Musa Thahir ${ }^{a^{*}}$, Yenita Roza $^{\mathrm{b}}$, Atma Murni $^{\mathrm{c}}$ \\ ${ }^{a, b, c}$ Postgraduate Study Program of Mathematics Education, University of Riau, Pekanbaru, Indonesia \\ *Corresponding author: musa.thahir7436@grad.unri.ac.id
}

\section{ARTICLE HISTORY}

Received May 11, 2018

Revised June 9, 2018

Accepted July 10, 2018

\section{KEYWORDS}

Validity

Website of Learning

Mathematics

\begin{abstract}
This article is based on the limited lecture model for Kapita Selekta Mathematics (KSM) courses. This article aims to reveal the results of technology validation of the website of the mathematics proficiency course (KSM) on UIN Suska Riau students. This article uses a development research model that uses Sugiyono's research steps but only limited to two stages, namely design stage and product validation stage. The validated aspect of the learning website is graphic feasibility and program feasibility with indicators: 1) the size of the learning website, 2) the design of the learning website, and 3) the design of the content of the learning website. The validation instrument is a questionnaire using Likert scale that is filled by three expert technology experts. Assessment of the validity of the learning web on the aspect of feasibility of the graphics resulted in a total validity value of 3.9 with valid categories. As for the web learning on the feasibility aspect of the program to produce the value of validity as a whole that is 4 with valid categories.
\end{abstract}

This is an open access article under the CC-BY-SA license.

\section{INTRODUCTION}

The study program in Mathematics Education at the Faculty of Teacher and Training of the State Islamic University of Suska Riau has the goal of printing mathematics educators who have pedagogic competence, professional competence, social competence and personality competence that has integration with Islamic values in learning mathematics. According Fitri, et al. (2014) that learning mathematics is a mental activity in gaining an understanding of the meaning that is then applied in real conditions. The learning process of mathematics is related to the ability of lecturers in using it as an effort to give the interpretation in solving mathematical problems. Therefore, the role of lecturers in the higher education is expected to the realization of goals and lecture stages in helping students achieve maximum learning.

According to the researcher's experience in teaching the last few years found various characteristics of learning mathematics, especially subjects Kapita Selekta Mathematics (KSM) courses, namely: 1) generally the lesson is applied with the lecture method, 2) the students are less involved in the cultivation of understanding, mathematical parables, and graphics, 3) the students get enough lecture material, 4) the lecture material presented has not been able to relate the concepts learned in high school based on personal experience, and 5) the less responsive activities involve students in the systematic problem-solving stage. It affects the KSM courses. Less qualified lectures as they have been presented beforehand packed against a less than an optimal understanding of concepts. It can be seen from the completeness of math-student learning through the results of final exams only $27 \%$ of the whole class that only able to get an A value, as much as $73 \%$ get less value than A. (Source: documentation of students KSM value of the study program in Mathematics Education at the Faculty of Teacher and Training of State Islamic University of Suska Riau from academic year 2016/2017).

The above facts indicate the need for improvement of lectures for math teacher prospectives. Among the efforts that can be done through improving the quality of education focused on the development of ability. Therefore, in learning mathematics required an interesting learning model and easy to understand by students. Based on this, it is necessary to apply a model of learning that can improve a student's motivation to learn.

One of the learning models that can improve a student's learning motivation is by using internet learning. According to Sulistyo, et al. (2016) is due to the development of an increasingly advanced era, as well as an increasingly growing curriculum that requires students to be creative in searching for economic learning materials that ultimately generate student interest in using the internet further. Motivation is also a driving factor in using the internet so that students will be encouraged in learning that eventually student also achievement will also increase. Furthermore, Zakaria and Nur Rahman (2016) that the influence of motivation and modern technological progress will certainly affect the development of the world can not be separated in the field of education, both in the field of education and in the process of obtaining or transfer of knowledge easily.

Learning can be done by lecturers and students through the use of the internet is a learning website. According to Febrian in Nuhrogo (2012) that the website is a system on the internet that allows anyone to be able to provide information. By using such technology the information can be accessed for 24 hours in one day and managed by the machine. According to Rusman in Aryaningrum (2016) that website-based learning (e-learning) is a learning activity that utilizes the media sites (websites) that 
can be accessed via the Internet network. Furthermore, he said with website-based learning (e-learning) especially web-enhanced course is expected that students do not get bored to listen to the teaching and learning process to the end, and also expected to make students think creative and active.

According to Kurniati, et al. (2014) that in this website-based learning (e-learning) process, the lecture material to be delivered is stored in a server computer both local and remote (long-distance). Furthermore, the user can display the course material by using internet browsing program such as Internet Explorer and Mozilla in a computer at study program, at home or in the internet cafe and using notebook or laptop and handphone. Thus, the learning of a website-based learning process as a medium of learning is very dependent on the availability of the Internet, although this process can be implemented in a computer lab or laptop and handphone by storing the necessary files.

Some relevant research for the writing of this article, namely: 1) Lawanto (2001) who said that website-based learning as a complex method of educational and training activities; 2) Sutanto (2009) that the process of implementing virtual learning with the concept of virtual classroom; 3) Tambunan (2013) that in the development of website-based learning in the electrical machine setting course; and 4) Tian and Suppasetseree (2013) that the development of interactive online listening task model for ELF learners in China. The results of this study show us that the lecture through the web provides demands not only the students' skills in using computers, reading and writing but also providing demands on transparent, disciplined and independent personal attitudes. In addition, lecture scenarios need to be prepared in a complex way to design website-based learning models. Implementation of website-based learning is not just positioning the course material on the web, but the combination of face-to-face meetings with website-based learning can provide increased contribution and inter-student activities. Thus it can be understood that through face-to-face students can know fellow students and lecturers. All the preparations ranging from making the schedule to determining how to communicate during the learning process take place are important processes in implementing website-based learning.

Based on the explanation, the researcher considers it necessary to conduct learning activities that lead to the learning process of students to increase student understanding of Kapita Selekta Mathematics course materials through the utilization of information technology, especially learning-websites that contain electronic materials so that students are not only lecture material but also anywhere and anytime. Through a research development, is expected to produce a quality product. In the development of this learning website, the resulting product is a mathematics learning website.

The quality of the product is seen from its validity, practicality, and effectiveness. However, in this article, the product quality is limited only to validity, especially to the validity of technology or media. Validity in development research includes content validity and construct validity. The validity of the construct means conformity between the product produced and the predetermined element of development. According to the Ministry of National Education (2008), that on the development of teaching materials in general "criteria assessed by experts include the components of content feasibility, linguistic components, components of the presentation, and components of construction". Based on the explanation, the validity of the learning website seen from two aspects, namely, the feasibility of graphics and program feasibility.

The result of requirement analysis which researcher has done in the previous article obtained by information that most of lecturers and student of the existence of website have the benefit and good quality to improve math learning. However, website-based learning (e-learning) has the main problems with its infrastructure facilities on $\mathrm{WiFi} /$ hotspot facility and lecturer's ability. The importance of the use of this website-based learning (e-learning) in the kapita selekta mathematics courses is because website-based learning (e-learning) has several advantages for the students, that is by using this learning: 1) students assisted in conducting lectures independently can be implemented in a deft, so that will increase and expand the understanding, learn social, ability to produce website, 2) excessive student conducting lecture because not only pay attention to lecturer's description but also other activities such as passing observation, direct role and others, 3) providing additional study origin that can be used for enriching the lecture material.

Based on these explanations, the researchers will do the design of web-based learning (e-learning) which will be presented in this article with the aim to reveal the results of technological validation from the subject website of kapita selekta mathematics on students of UIN Suska Riau.

\section{RESEARCH METHOD}

This article uses a model of research development that uses Sugiyono's research steps but is limited only to two stages, namely the design stage and product validation stage. The validated aspect of the learning website is graphic feasibility and program feasibility with indicators: 1) the size of the learning website, 2) the design of the learning website, and 3) the design of the content of the learning website. The validation instrument is a questionnaire using the Likert scale that is filled by three expert technology experts. Data analysis used is a descriptive analysis through a Likert scale.

\section{RESULTS AND DISCUSSION}

The development procedure in this research is Sugiyono development steps by modifying Borg and Gell development model. Explanation of procedure and result data from research stage can be explained in detail as follows:

\subsection{Product desisgn phase}

Stage of product design of learning website consists of three main stages, among others: preparation of materials, preparation of questionnaires/questionnaires and the development of initial product formats. Carefully presented in the following description.

\subsubsection{Preparation of material}

The material in this math learning website is presented for one semester with details as follows: 1) Functions, Composition Functions, and Inverse Functions; 2) Understanding and the types of skunk, determining the value of skunk with various methods, and inter-skunk operation; 3) Similarity skunk, a division of skunk with linear divisors, a division of skunk with quadratic dividers; 4) The remaining theorem, Factor theorem, Propane roots, Vieta Theorem; 5) Understanding of sequence and series, Sigma notation and its nature, Row and aritmetic series, Rows and geometry series; 6) Rows, middle tribes, 
inserts, and arithmetic series, Rows, middle tribes, inserts, and geometry series; 7) Unlimited geometry series and Applications of sequence and arithmetic and geometry series; and 8) Comparison of trigonometry in right triangles, related angles, identity, sine and cosine rules.

These materials are not new material known to students because they have been reviewed during high school and middle school. The material will help researchers to develop the characteristics of the website related to the cognitive, affective, and psychomotor aspects of the students. With these materials the website to be developed is a math learning website.

\subsubsection{Preparation of questionnaire}

In the preparation of this research instrument using validation assessment questionnaire. The validation sheet used is a questionnaire. The answer criteria are very valid, valid, valid enough, less valid, very invalid with consecutive values $5,4,3,2$, 1. The validation assessment questionnaire is filled by three validators of the technology. Medium of technology validators will conduct assessments regarding feasibility aspects of program gradability and eligibility. For more details will be presented lattice instrument questionnaire validation medium validation in the following table.

Table 1. Grid Instrument Validation Assessment Media

\begin{tabular}{lll}
\hline No & \multicolumn{1}{c}{ Criteria } & \multicolumn{1}{c}{ Indicator } \\
\hline \multirow{3}{*}{1} & Aspects of Eligibility & 1.1. Web Size of Learning \\
& and Programming & 1.2. Web Design Learning \\
& & 1.3. Web Content Design \\
\hline
\end{tabular}

\subsubsection{Development of Initial Product Formats}

After data collection and instrument preparation, the next step is to develop the initial product format. Presentation of the development of math learning website subjects kapita selekta mathematics is the description of the website development results. Description of the website development results in the form of a brief description of the contents of the website learning mathematics subjects kapita selekta mathematics. The following will be presented diagrams of math learning website.

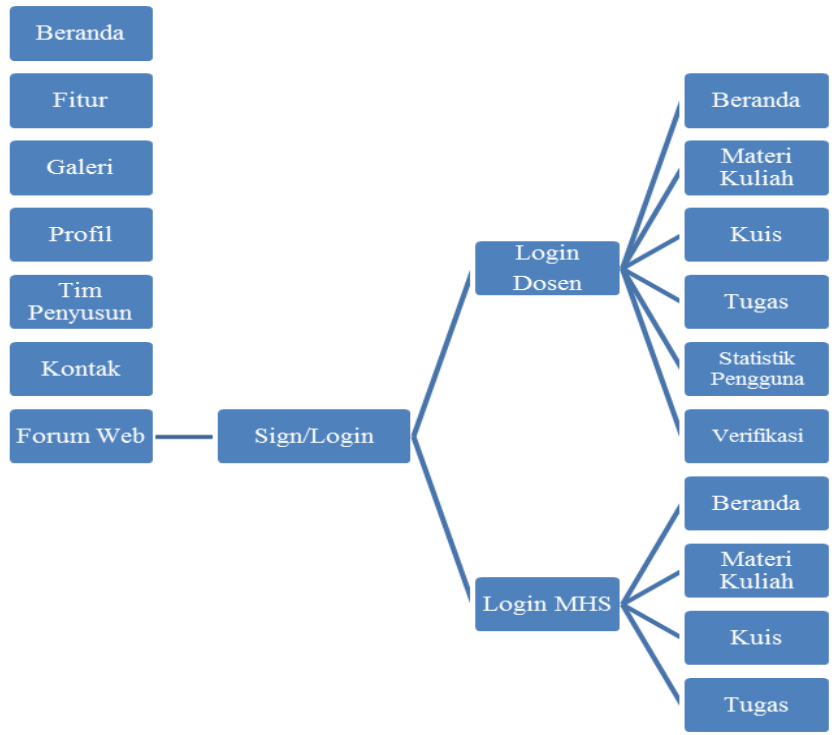

Fig 1. Diagram of mathematics learning website
For more details, the following will explain the function of each of each menu.

\section{Home}

On the home page consists of writing WP MATH (learning websites) MATH, Welcome To Mathematics Learning Web Browser, Welcome and May Helpful, and Learn More. The selected image on this homepage is tailored to the subject matter of learning that is math learning. The home page layout is arranged in such a way as to attract the attention of students to use this website. The results of the design and development of web learning can be seen in the following figure.

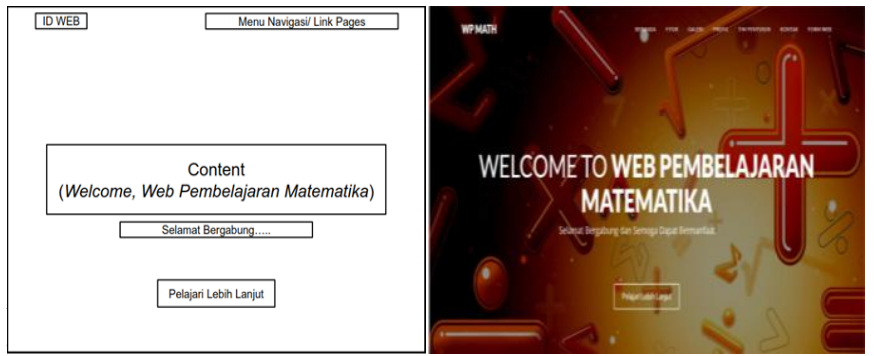

Fig 2. Results of design and development of the webpages learning home page

The Feature Page in our system simplifies learning without getting stuck in the classroom with some benefits that the researcher provides: 1) online module sharing, on this system, will be provided with modules and other online resources; 2) online discussions, is discussing material online; 3) online announcements, which convey matters related to subsequent meetings, and the discussion and presentation of questions; and 4) interaction, is more active interaction between lecturers and students online. Anything from the design and development of web learning can be seen in the following figure.

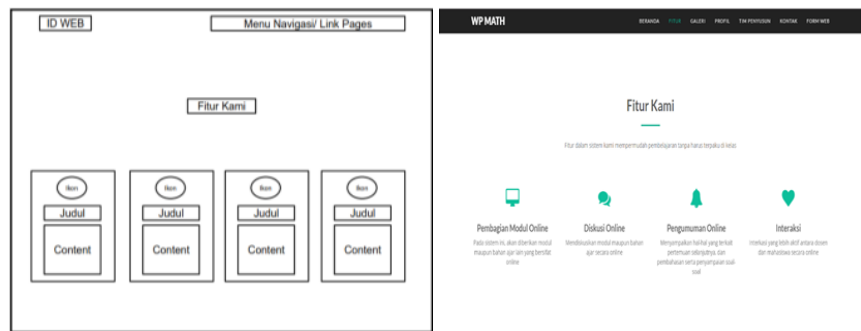

Fig 3. Results of design and development of the fiturs

\section{Gallery}

The Gallery page contains the documentation of Course Activities and Other Activities in study program of mathematics education, such as: lecture activities, lecturers meeting activities, and activities of the updated course of mathematics education. The results of the design and development of web learning can be seen in the following figure.

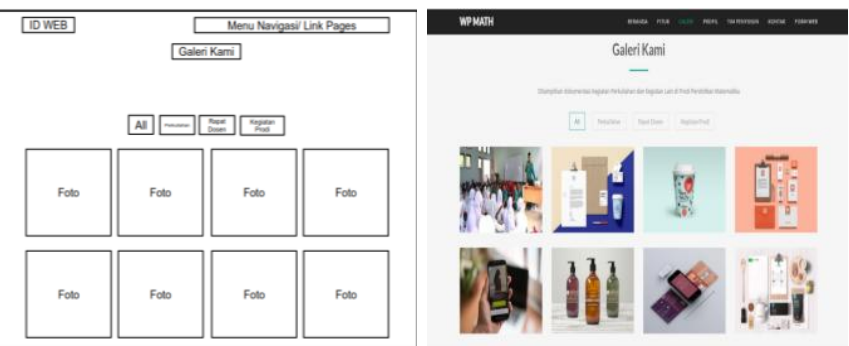

Fig 4. Results of design and development of the "Galleri" menu 


\section{Profile}

On the profile page it contains about who designed, what is designed, and what is on the website. The results of the design and development of web learning can be seen in the following figure.
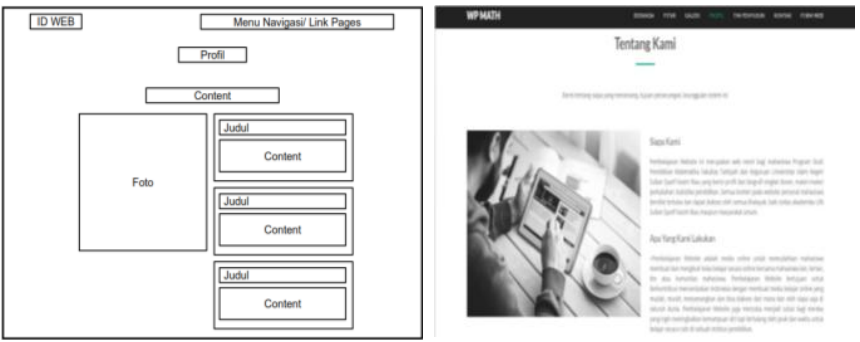

Fig 5. Results of design and development of the "Profil" menu

\section{Compiler Team}

This Compiler Team page contains about the people involved in the process of composing the mathematics learning website that has the competence according to the needs of system design. First, Musa Thahir is a master of mathematics education program of Faculty of Teacher and Training, University of Riau who made the idea of website development. Second, Dra. Yenita Roza, $\mathrm{Ph} . \mathrm{D}$ is the one mentor who helps researchers in drafting proposals and thesis. Third, Dr. Atma Murni, M.Pd. who is the two mentors who also assist in drafting the proposal and thesis. Fourth, Lukmanul Hakim, MTA. which is a great student of State Islamic University of Suska Riau who has much experience in making website that helps researchers in programming this math learning website. The results of the design and development of web advocacy can be seen in the following figure.
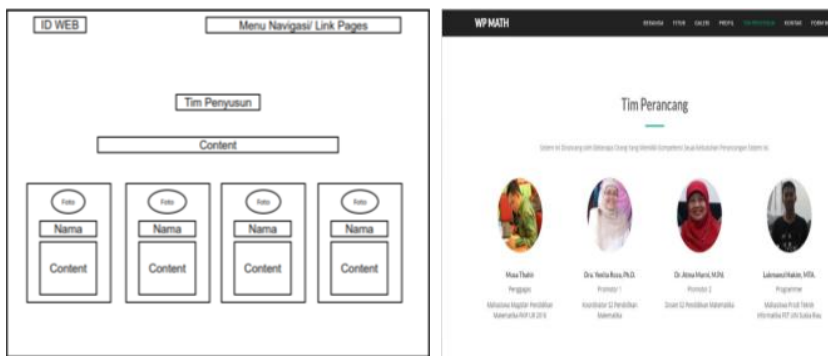

Fig 6. Results of design and development of the "tim penyusun" menu

\section{Contact}

On the contact page contains the address and contact researcher to help students and other visitors who experience obstacles or need information about this learning website. The results of the design and development of web learning can be seen in the following figure.
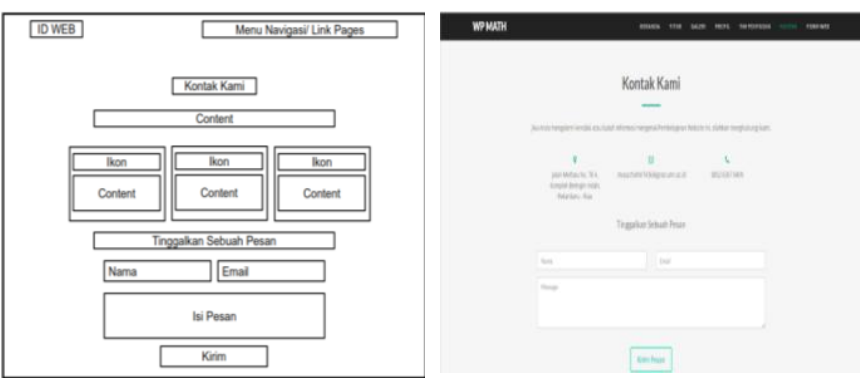

Fig 7. Results of design and development of the "kontak" menu

\section{Forum Web}

On this web forum page, users either lecturers want to be students will login first. But before that, lecturers and students must register first by registering first name, last name, email and password. The results of the design and development of web learning can be seen in the following figure.
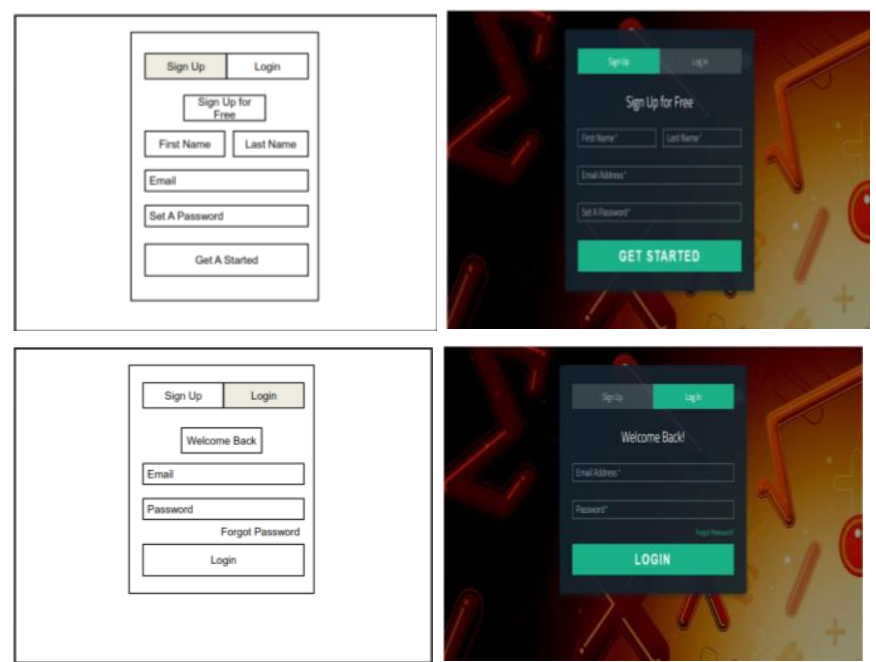

Fig 8. Results of design and development of the "forum web" menu (sign up and login)

After login, lecturers and students will be presented a different menu. For more details, will be described below.

\section{a. Login Lecturer}

When the lecturer has successfully login, then on the page mentioned will be presented several menus, among others:

1) Home

This menu serves to present the outline KSM course. The results of the design and development of web learning can be seen in the following figure.
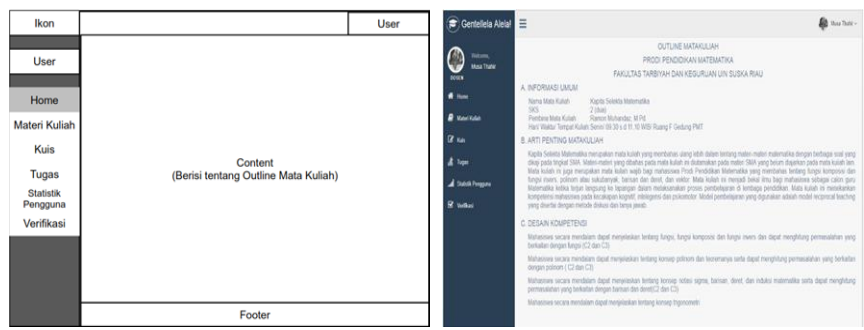

Fig 9. Results of design and development of the "forum web" menu (home)

\section{2) Course Material}

This menu serves to help lecturers to enter lecture material at each meeting. The inputs can be text (PDF, PPT, Word) and video/audio. In addition, the menu also serves to input the questions that are given time constraints. In addition, on this menu there is also a sub menu task that contains the task given by the lecturer to be done at home with the time limit that has been fixed by the lecturer. The results of the design and development of web learning can be seen in the following figure. 

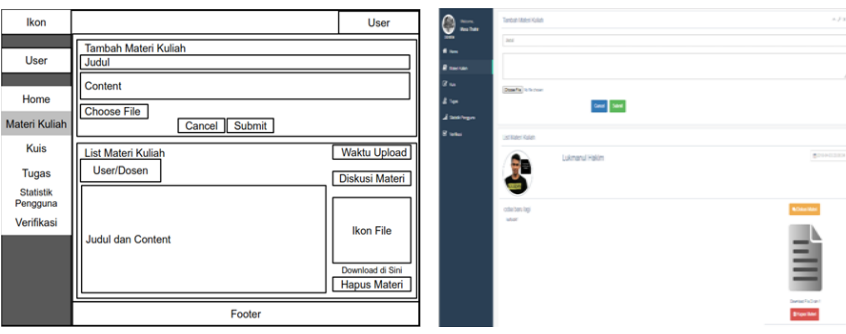

Fig 10. Results of design and development of the forum web menu (course material)

\section{3) Quiz}

This menu serves to present the quizzes given every 4 (four) meetings in the form of a description. The results of the design and development of web learning can be seen in the following figure.

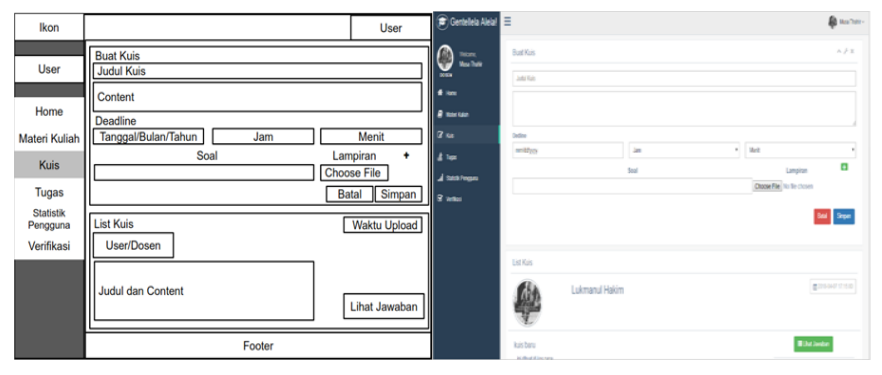

Fig 11. Results of design and development of the kuis menu

\section{4) Assigne}

This menu serves to present the tasks assigned to each meeting in the form of a description. The results of the design and development of web learning can be seen in the following figure.
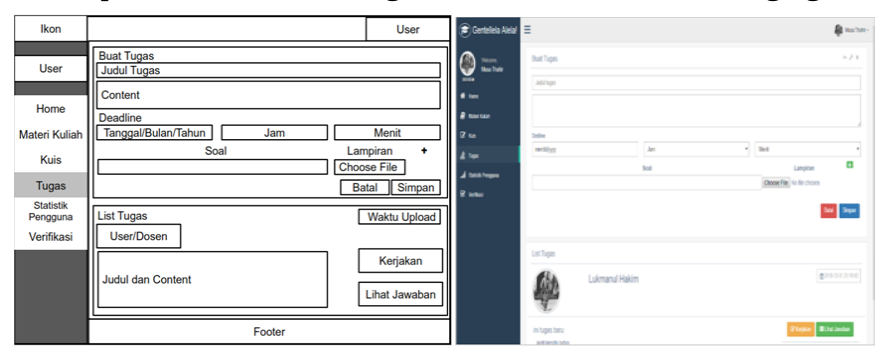

Fig 12. Results of design and development of the tugas menu (assigne)

\section{5) User Statistics}

This menu serves to see how active students in using this math learning website. The results of the design and development of web learning can be seen in the following figure.
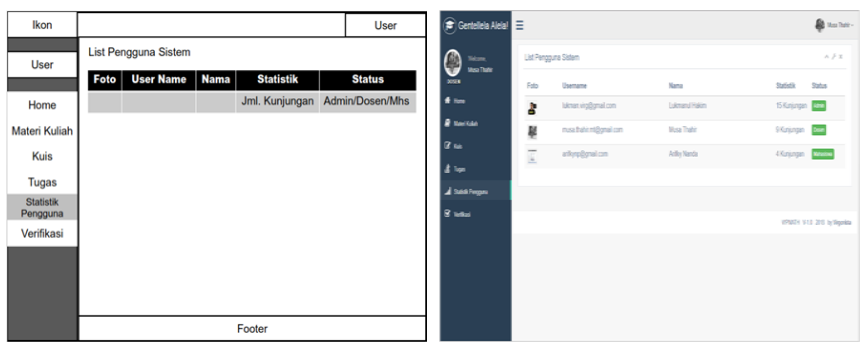

Fig 13. Results of design and development of the statistik pengguna menu (user statistics)

\section{6) Verification}

This menu serves to verify the user who signed up on the web form and make sure the user is actually a student in the test class. The results of the design and development of web learning can be seen in the following figure.
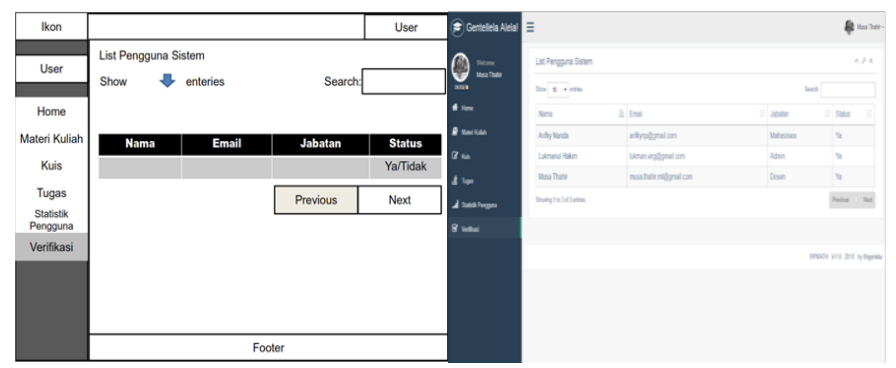

Fig 14. Results of design and development of the Verifikasi (verification)

\section{b. Login Students}

In addition to lecturers, students will also log into web forums. When the student has successfully login, then on the page will be presented some menu, among others:

\section{1) Home}

This menu serves to see the outline of KSM course. The results of the design and development of web learning can be seen in the following figure.
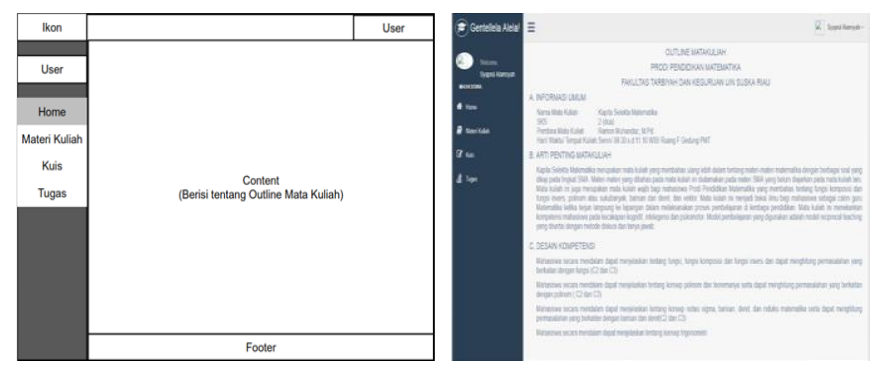

Fig 15. Results of design and development of the home menu

\section{2) Course Materials}

This menu serves to view the lecture material at each meeting in the form of a file or video. The results of the design and development of web learning can be seen in the following figure.
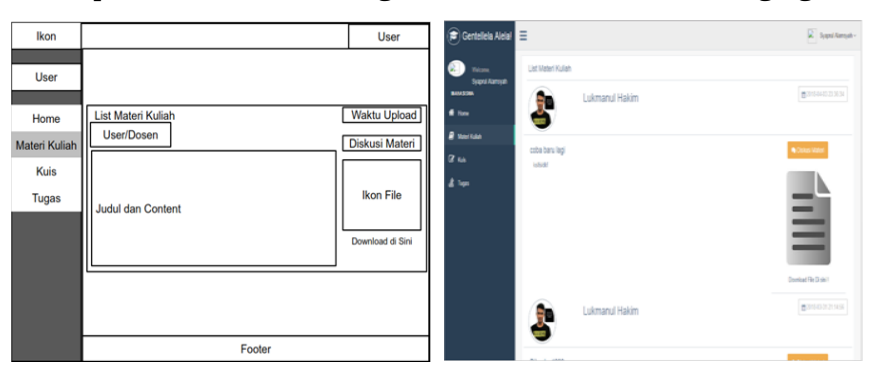

Fig 16. Results of design and development of the course materials menu

\section{3) Quiz}

This menu is used to view quiz list created by lecturer. In addition, on this menu can also serve to see the champion on each given quiz and see the progress of student learning. The results of the design and development of web learning can be seen in the following figure. 

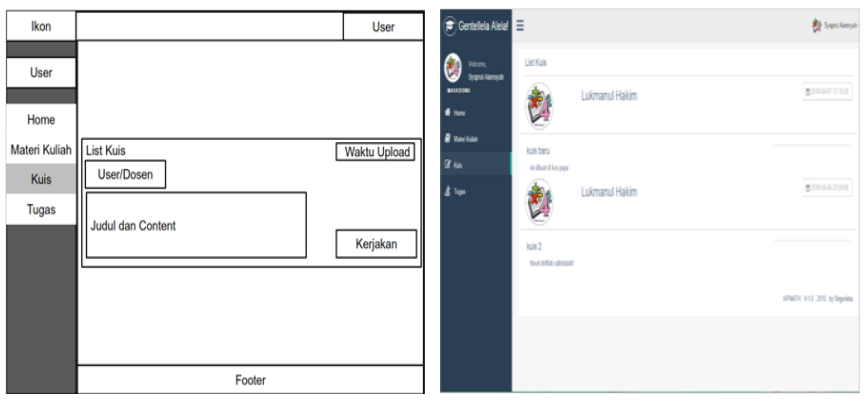

Fig 17. Results of design and development of the kuis (quiz)

\section{4) Assigne}

This menu serves to to see the list of tasks made by lecturers. The results of the design and development of web learning can be seen in the following figure.

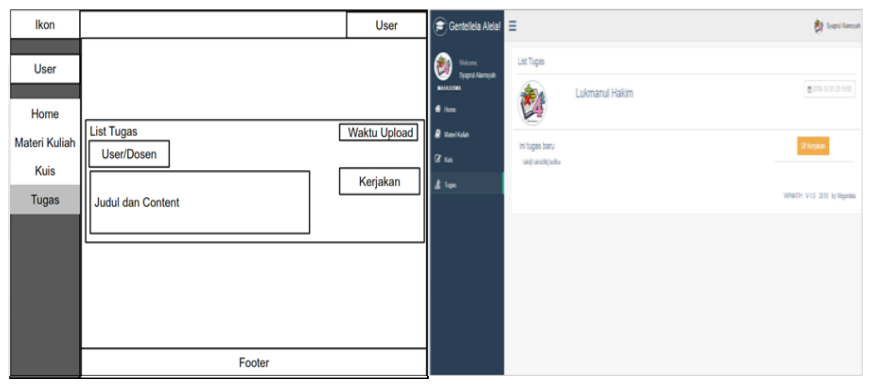

Fig 18. Results of design and development of the tugas menu (assigne)

\subsection{Product Validation Stage}

Prior to use in lecture activities, this learning web must be able to have a "valid" status. Ideally, a technology developer needs to get a judgment from the experts (validator) about the feasibility of the program and the graduation until it is judged well by the validator. Stages of validation is expected to provide a reasonable assessment on a website so that it can be used for lecturing process. That is, by obtaining valid or highly valid status from experts. If the learning technology in the form of website is not yet valid, then validation will continue to be done until obtained a valid website.

In this research, the validation sequence process is carried out for 7 (seven) days, with validator that they are competent and understand about the preparation of learning web and able to give input/suggestion to improve learning media which have been prepared. Suggestions from the validator will be used as materials to revise this learning web.

Table 2. Web Learning Validation Results by Experts

\begin{tabular}{clcc}
\hline No & \multicolumn{1}{c}{ Grain Assessment } & Means & Category \\
\hline Aspect of Channel Feasibility & & \\
\hline 1 & $\begin{array}{l}\text { Selection of website size can be } \\
\text { adjusted on display on android }\end{array}$ & 4 & Valid \\
\hline 2 & $\begin{array}{l}\text { Interesting website design } \\
\text { mathematics learning }\end{array}$ & 4 & Valid \\
\hline 3 & Displays a good center point & 4 & Valid \\
\hline 4 & $\begin{array}{l}\text { The menu structure presented } \\
\text { is consistent }\end{array}$ & 4 & Valid \\
\hline 5 & $\begin{array}{l}\text { Appropriateness of use of } \\
\text { color, writing and background } \\
\text { design }\end{array}$ & 3 & Valid \\
\hline 6 & The text in the learning website & 4 & Valid \\
\hline
\end{tabular}

\begin{tabular}{|c|c|c|c|}
\hline & can be read clearly & & \\
\hline 7 & $\begin{array}{l}\text { Views of learning websites have } \\
\text { different characteristics with } \\
\text { other websites }\end{array}$ & 4 & Valid \\
\hline 8 & $\begin{array}{l}\text { Display and layout of learning } \\
\text { websites in accordance with } \\
\text { the profile of the website }\end{array}$ & 4 & Valid \\
\hline 9 & $\begin{array}{l}\text { Placement of menus do not } \\
\text { interfere with the view }\end{array}$ & 4 & Valid \\
\hline 10 & $\begin{array}{l}\text { Learning website contains the } \\
\text { concept of subjects selekta } \\
\text { mathematics subject to Capain } \\
\text { Learning / KD }\end{array}$ & 4 & Valid \\
\hline \multicolumn{4}{|c|}{ Program Feasibility Aspect } \\
\hline 11 & $\begin{array}{l}\text { Learning Websites are easy for } \\
\text { users to operate }\end{array}$ & 4 & Valid \\
\hline 12 & $\begin{array}{l}\text { The navigation structure is } \\
\text { easy to remember by students }\end{array}$ & 4 & Valid \\
\hline 13 & $\begin{array}{l}\text { Learning Websites have a high } \\
\text { level of reliability }\end{array}$ & 4 & Valid \\
\hline 14 & $\begin{array}{l}\text { The navigation buttons are } \\
\text { consistent throughout the } \\
\text { contents of the Learning } \\
\text { Websites }\end{array}$ & 4 & Valid \\
\hline 15 & $\begin{array}{l}\text { Easy to get the latest } \\
\text { information }\end{array}$ & 4 & Valid \\
\hline 16 & $\begin{array}{l}\text { The hierarchy of menus is } \\
\text { clear, consistent and } \\
\text { proportional }\end{array}$ & 4 & Valid \\
\hline 17 & $\begin{array}{l}\text { Ease of contacting contact } \\
\text { person when needing } \\
\text { information }\end{array}$ & 4 & Valid \\
\hline 18 & $\begin{array}{l}\text { Accurate function of button } \\
\text { and a menu with desired } \\
\text { purpose }\end{array}$ & 4 & Valid \\
\hline 19 & $\begin{array}{l}\text { Learning Websites can be } \\
\text { opened on all browsers well }\end{array}$ & 4 & Valid \\
\hline 20 & $\begin{array}{l}\text { Speed of opening the Learning } \\
\text { Website page in either program }\end{array}$ & 4 & Valid \\
\hline
\end{tabular}

In Table 2 it can be seen that the results of validity test of web learning for each aspect is valid. For the feasibility aspect of graffiti is appropriate and can be said valid by obtaining validity value in the range of 3.9 with valid category. This means that from the aspect of feasibility of kegrafisan, web designed learning is valid according to experts. In the feasibility aspect of the program, this web learning is valid by obtaining the value of the validity in the range 4 for each aspect with a valid category. This means that this learning web can be said to be valid according to the experts.

Validation results by some of the validators, there are some suggestions for improving learning web. The validator provides suggestions for: 1) needing improvement and coloring arrangements; 2) background composition needs to be styled to be more slick; and 3) add icon lecturers and students. Based on the suggestion from the validator, the researcher make improvements to these suggestions, and based on product quality according to Nieeven (2013) physics-assisted web-based learning media has met the valid quality. It shows that according to the validator of physics-assisted learning media web without network is valid and can be used in a learning process. 


\section{CONCLUSION}

Based on the results and discussion on the above description, the developed learning web has been said to be valid and has been feasible to use. Assessment of the validity of the learning web on the aspect of feasibility of the graphics resulted in a total validity value of 3.9 with valid categories. As for the web learning on the feasibility aspect of the program to produce the value of validity as a whole that is 4 with valid categories.

\section{ACKNOWLEDGEMENTS}

The author would like to thank the team of mentors who have provided maximum guidance for the completion of this article.

\section{REFERENCES}

Aryaningrum, K. (2016). Pengaruh Pembelajaran Berbasis Web (E-Learning) terhadap Hasil Belajar Siswa Pada Mata Pelajaran Geografi Kelas XI di SMA Negeri 9 Palembang, Jurnal Media Penelitian Pendidikan, 10 (2), 154-162.

Depdiknas. (2008). Panduan Pengembangan Bahan Ajar. Direktorat Pembinaan SMA. Jakarta.

Fonna, M., \& Mursalin, M. (2018). Role of Self-Efficacy Toward Students' Achievement in Mathematical Multiple Representation Ability (MMRA). Jurnal Imiah Peuradeun, 6(1), 31-40.

Kurniati, D., Trapsilasiwi, D. (2014). Pengembangan Model Pembelajaran Analisis Real Berbasis Web Dalam Bentuk E-Learning, Jurnal Kadikma, 5 (3), 1-12.

Mursalin, M. (2011). Penerapan Strategi Pembelajaran Kreatif-Produktif Dalam Meningkatkan Pemahaman Konsep Matematika Siswa Kelas VII SMPN 2 Meurah Mulia. Jurnal Tadirs Matematika, 2(3), 1-12.

Mursalin, M. (2014). Pengembangan Buku Siswa Materi Aritmetika Sosial Berbasis Pembelajaran Model Treffinger Untuk Mendukung Kemampuan Berpikir Kreatif Siswa SMPN 19 Malang.Jurnal Pascasarjana Universitas Negeri Malang, 2(3), 1-23

Mursalin, M. (2016). Pembelajaran Geometri Bidang Datar di Sekolah Dasar Berorientasi Teori Belajar Piaget. DIKMA (Jurnal Pendidikan Matematika), 4(2), 250-258.

Nugroho, A. (2012). Pengembangan Model Pembelajaran Jarak Jauh Berbasis Web, Jurnal Transformatika, 9 (2), 72-76.

Rahma Fitri, Helma, Hendra Syarifuddin. (2014). Penerapan Strategi The Firing Line Pada Pembelajaran Matematika Siswa Kelas XI IPS SMA Negeri 1 Batipuh. Jurnal Pendidikan Matematika, 3 (1), 18-22.

Wulandari, V.C., Sulistiyo, Yudiono, U. (2016). Pengaruh Pemanfaatan Internet, Kebiasaan Belajar dan Motivasi Belajar Siswa terhadap Prestasi Belajar Ekonomi Siswa Kelas XI IPS di SMA Negeri 02 Malang, Jurnal Riset Pendidikan Ekonomi, 1 (2), 1-12.

Zakaria, M.I., Rokhman, M.N. (2016). Pengaruh Motivasi dan Penggunaan Internet terhadap Prestasi Belajar Siswa Dalam Pembelajaran Sejarah di MAN 2 Yogyakarta Tahun Ajaran 2015/2016, Jurnal Risalah, 1 (2).

License information: This is an open-access article distributed under the terms of the Creative Commons Attribution License, which permits unrestricted use, distribution, and reproduction in any medium, provided the original work is properly cited. 